OPEN ACCESS

Edited by:

Lu Lu,

China University of Mining and

Technology, China

Reviewed by:

Huichuan Liu,

China University of Petroleum, China Jian-Jun Fan,

Jilin University, China

*Correspondence:

Zhang Yuquan zhangyuquangig@163.com

Li Zian

lizian88@126.com

Specialty section:

This article was submitted to

Geochemistry,

a section of the journal

Frontiers in Earth Science

Received: 16 September 2021

Accepted: 07 December 2021

Published: 07 February 2022

Citation:

Shaogong Z, Yingjie L, Yuquan Z and Zian L (2022) Zircon U-Pb Dating for Paragneiss in the Xinxian Area in the Dabie-Sulu Orogenic Belt and lts Geochemical Characteristics. Front. Earth Sci. 9:778377. doi: 10.3389/feart.2021.778377

\section{Zircon U-Pb Dating for Paragneiss in the Xinxian Area in the Dabie-Sulu Orogenic Belt and Its Geochemical Characteristics}

\author{
Zhu Shaogong ${ }^{1}$, Liang Yingjie ${ }^{2,3}$, Zhang Yuquan ${ }^{2 *}$ and Li Zian ${ }^{4 *}$ \\ ${ }^{1}$ The 2nd Oil Production Plant of Daqing Oilfield Limited Company, Daqing, China, ${ }^{2}$ Key Lab of Mineral and Mineralization, Chinese \\ Academy of Sciences, Guangzhou Institute of Geochemistry, Guangzhou, China, ${ }^{3}$ Guangzhou Institute of Geochemistry, Chinese \\ Academy of Sciences (GIGCAS), Beijing, China, ${ }^{4}$ School of Marine Sciences, Sun Yat-sen University, Guangzhou, China
}

In order to understand the subduction of the Yangtze block and its collision with the North China Craton, we performed the elements analysis and zircon U-Pb dating on paragneiss from Xinxian area, which located along the west edge of the Dabie-Sulu ultrahigh-pressure (UHP) metamorphic belt. The major elements analysis showed $\mathrm{SiO}_{2}, \mathrm{Al}_{2} \mathrm{O}_{3}$, and $\mathrm{K}_{2} \mathrm{O}$ were enriched and the rare-earth element (REE) analysis showed the paragneiss had a high content of REEs, especially light rare Earth elements (LREEs). The elements analysis suggest that the protolith of paragneiss may be formed by terrestrial materials. As reflected by cathode luminescence (CL), zircon in rocks was metomorphic and had a core-edge microstructure. The edge of zircon was dated by LA-ICP-MS at $233 \pm 24 \mathrm{Ma}$, which suggests that the paragneiss was formed later than the Triassic. The inherited zircon had a large age range of 456-1,727 Ma, mainly in the range of 705-811 Ma. The wide range of ages suggests that the protolith of paragneiss was sedimentary rocks formed no earlier than the Paleozoic. And the paragneiss from Xinxian area were generated in the Dabie-Sulu ocean basin or abortive ocean basin in the Paleozoic era.

Keywords: zircon U-Pb age, dabie-sulu UHP metamorphic belt, paragneisses, xinxian, protolith of paragneiss

\section{INTRODUCTION}

As one of the largest UHP metamorphic belts in the world, the Dabie-Sulu belt, located between the northern margin of the Yangtze Craton and the southern margin of the North China Craton, has received much attention. It has been widely investigated since the discovery of coesite and microgranular diamond in its eclogite (Okay et al., 1989; Wang et al., 1989; Shutong et al., 1992; Shu-tong et al., 2003). Many geochronological researches have shown that the Dabie-Sulu UHP metamorphic belt was formed by the subduction of the Yangtze block and its collision with the North China Craton during the Triassic (Liu et al., 2003; Shu-tian and You, 2005). The tectonic evolution of the subduction-collision was recorded by the rock assemblies in this metamorphic belt.

The metamorphic belt is mainly composed of eclogite, gneiss and jadeitite quartzite, among which gneiss is the dominant rock and accounts for a larger proportion than any other rock (Dao-gong et al., 2000; Wang et al., 2000; Zheng et al., 2000; Liu et al., 2004). Some geochronological and geochemical studies showed that the protolith of gneiss was related to the Neoproterozoic rift magmatism on the northern edge of the Yangtze block (Zheng et al., 2003; Zheng et al., 2006). Besides, other studies found that the protolith also contained Paleoproterozoic and Archean 


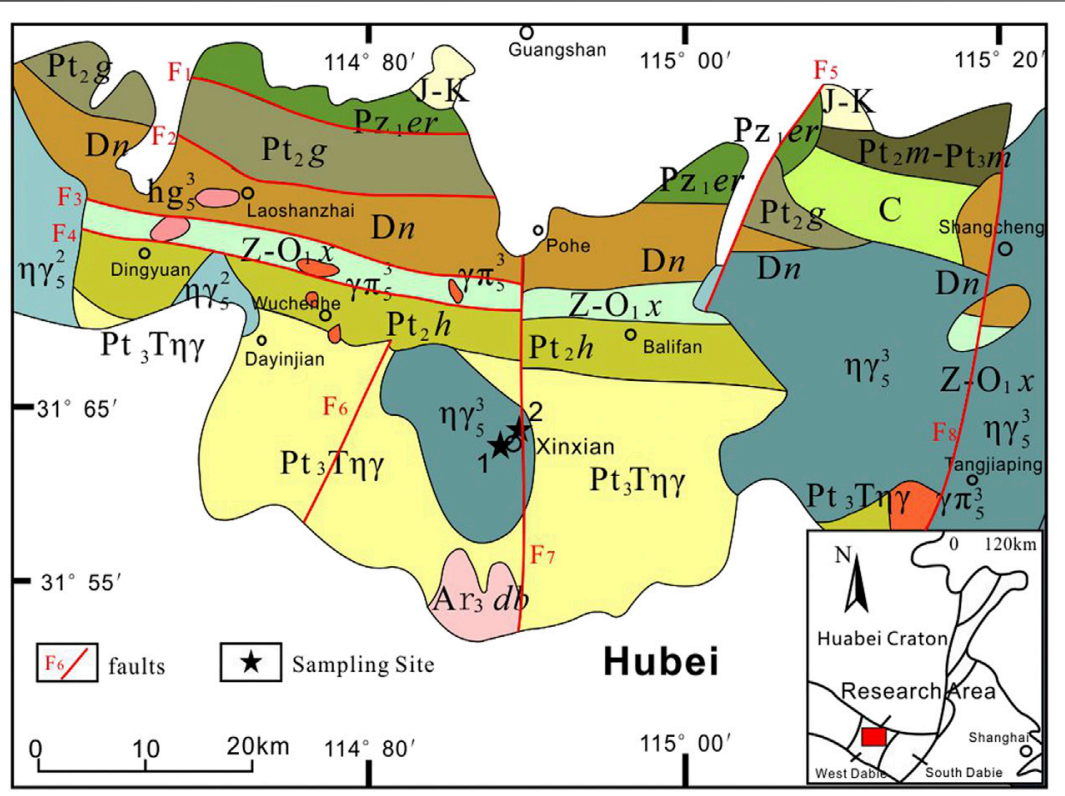

FIGURE 1 | Geological map of the Xinxian area in the Dabie orogenic belt (modified after Kun-guang et al., 2009; Dong-xing et al., 2011). J-K, Jurassic-Cretaceous volcanic rocks and volcano-sedimentary rocks; Kc, Lower Cretaceous Chenpeng Formation; Dn, Devonian Nanwan Formation; Pz ${ }_{1}$ er, Lower Paleozoic Erlangping Group; Z-O ${ }_{1}$, Sinian-Lower Ordovician Xiaojiamiao Formation-Complex; $\mathrm{Pt}_{2} h$, Middle Proterozoic Huwan Formation-Complex; Pt $2 g$, Middle Proterozoic Guishan Formation-Complex; $\mathrm{Ar}_{3} \mathrm{db}$, Neoarchean Dabie Formation-Complex; $\eta \gamma_{5}^{3}$, Late Yanshanian monzonitic granite; $\gamma \pi_{5}^{3}$, Yanshanian granite porphyry; $h g_{5}^{3}$, Yanshanian quartz diorite; $\mathrm{Pt}_{3} \mathrm{~T} \eta \gamma$, Neoproterozoic Tianpu Sequence granite paragneiss.

metamorphic rocks and some Neoproterozoic and Paleozoic granites (Chen et al., 2013). Geochronological and geochemical analysis of gneiss is helpful for the determination of the characteristics of the protolith and understanding of the magmatic activities of the Yangtze Plate during different ages. Meanwhile, it also helps to understand the subduction of the Yangtze block and its collision with the North China Craton.

Although several geochronological and isotopic studies on metamorphic rocks in the Dabie-Sulu UHP metamorphic belt were carried out in the 1990s, most of them only focused on the northern Dabie area in the east of the metamorphic belt ( $\mathrm{Wu}$ et al., 2001). The researches of the Xinxian area at the western edge of the metamorphic were largely limited to eclogite and gneiss (Wang et al., 1993; Xue-xie et al., 1993), while paragneiss was less studied (Yang et al., 2009; Yang et al., 2009). Based on these previous studies, we investigated the paragneiss and ages of zircon in paragneiss and further discussed the protolith of paragneiss.

\section{REGIONAL GEOLOGY}

The paragneiss in the Xinxian area is distributed in the west edge of the Dabie-Sulu UHP metamorphic belt and is classified into the quartz andesite gneiss assemblage as shown on the 1:500,000 geological map of the Dabieshan orogenic belt (Figure 1): The assemblage refers to mica plagioclase gneiss with lenticles of marble, jadeitite, and eclogite $\left(\mathrm{YG}_{1}\right)$ and mica plagioclase gneiss with lenticles of eclogite $\left(\mathrm{YG}_{2}\right)$ (Shu-tong et al., 2005). Outcropping strata in the Xinxian area mainly include the
Lower Paleozoic Erlangping Group $\left(\mathrm{Pz}_{1}\right.$ er), Middle Proterozoic Huwan Formation $\left(\mathrm{Pt}_{2} \mathrm{~h}\right)$, Middle Proterozoic Guishan Formation-Complex $\left(\mathrm{Pt}_{2} \mathrm{~g}\right)$, Sinian to Ordovician Xiaojiamiao Formation $\left(\mathrm{Z}-\mathrm{O}_{1} \mathrm{x}\right)$, Devonian Nanwan Formation (Dn), Lower Cretaceous Chenpeng Formation (Kc), and Quaternary (Q).

The paragneiss in the Xinxian area was earlier classified into the Archean Dabie Group $\left(\mathrm{Ar}_{3} \mathrm{db}\right)$ and Neoproterozoic Tianpu Sequence granite paragneiss $\left(\mathrm{Pt}_{3} \mathrm{~T} \eta \gamma\right)$. It is dominated by the Dabie gneissic complex composed of metamorphic supracrustal rocks and metamorphic plutonic rocks. Metamorphic supracrustal rocks consisted of biotite monzonite paragneiss, plagioclase hornblende paragneiss, dolomite quartz schist and magnetite quartzite, among others. Metamorphic plutonic rocks were composed of monzonite granite gneiss, muscovite diorite paragneiss and biotite plagioclase paragneiss (Liu et al., 2004). The Archean Dabie Group $\left(\mathrm{Ar}_{3} \mathrm{db}\right)$ is distributed in the TongbaiDabieshan subzone of the Qinling Stratigraphic Zone and is the oldest strata of the Qinling Fold System. It mainly outcrops in the mountainous area at the junction of the three provinces of Henan, Hubei, and Anhui, and its main body is located in the territories of Hubei and Anhui provinces. This group was composed of quartz schist, biotite schist, dolomite plagioclase paragneiss, dolomite monzonite paragneiss, biotite plagioclase paragneiss, hornblende diorite paragneiss and banded migmatite, etc. It is in unconformable contact with the underlying Archean Dabie Group.

Paragneiss samples were collected for subsequent analysis from the Xinxian Qianhe quarry and the north of Xinxian county (the No. 1 and 2 sampling points marked by black stars in Figure 1). Samples QH-1, QH1A, and QH-2 were 
TABLE 1 | Analytical results of major (\%) and trace elements $(\mu \mathrm{g} / \mathrm{g})$ for the Xinxian paragneisses.

\begin{tabular}{|c|c|c|c|c|c|c|c|c|c|c|c|c|c|c|c|c|c|}
\hline Samples & QH-1 & QH-2 & QH-3 & XX4-1 & XX4-2 & Samples & QH-1 & QH-2 & QH-3 & XX4-1 & XX4-2 & Samples & QH-1 & QH-2 & QH-3 & XX4-1 & $x \times 4-2$ \\
\hline $\mathrm{SiO}_{2}$ & 76.42 & 76.10 & 76.41 & 75.93 & 68.29 & As & 8.22 & 8.56 & 8.86 & 0.00 & 0.00 & $\mathrm{Ba}$ & 162.00 & 167.00 & 181.00 & 864.90 & 1176.60 \\
\hline $\mathrm{TiO}_{2}$ & 0.09 & 0.09 & 0.10 & 0.18 & 0.56 & $\mathrm{Li}$ & 1.30 & 1.15 & 1.65 & 0.00 & 0.00 & $\mathrm{Hf}$ & 9.80 & 8.76 & 8.73 & 7.16 & 4.90 \\
\hline $\mathrm{Al}_{2} \mathrm{O}_{3}$ & 11.65 & 11.58 & 11.91 & 12.58 & 16.06 & $\mathrm{Be}$ & 4.17 & 3.79 & 4.90 & 0.00 & 0.00 & $\mathrm{Ta}$ & 1.68 & 1.61 & 1.81 & 1.05 & 0.77 \\
\hline $\mathrm{Fe}_{2} \mathrm{O}_{3}$ & 1.56 & 1.56 & 1.49 & 1.59 & 3.02 & Sc & 3.94 & 4.37 & 4.17 & 4.26 & 6.55 & W & 0.48 & 1.06 & 0.35 & 0.00 & 0.00 \\
\hline $\mathrm{MnO}$ & 0.03 & 0.03 & 0.04 & 0.06 & 0.07 & V & 1.35 & 0.72 & 2.18 & 6.42 & 30.27 & $\mathrm{Tl}$ & 0.40 & 0.40 & 0.45 & 0.00 & 0.00 \\
\hline $\mathrm{MgO}$ & 0.00 & 0.00 & 0.00 & 0.15 & 1.07 & $\mathrm{Cr}$ & 12.30 & 18.70 & 6.98 & 307.50 & 213.10 & $\mathrm{~Pb}$ & 17.40 & 17.00 & 20.60 & 16.74 & 11.29 \\
\hline $\mathrm{CaO}$ & 0.13 & 0.17 & 0.26 & 0.14 & 0.53 & Co & 0.91 & 0.82 & 0.62 & 2.81 & 4.28 & $\mathrm{Bi}$ & 0.07 & 0.05 & 0.08 & 0.00 & 0.00 \\
\hline $\mathrm{Na}_{2} \mathrm{O}$ & 4.09 & 3.90 & 4.07 & 3.70 & 4.43 & $\mathrm{Ni}$ & 5.92 & 7.84 & 3.22 & 20.96 & 14.73 & Th & 10.20 & 11.30 & 11.70 & 9.22 & 8.40 \\
\hline $\mathrm{K}_{2} \mathrm{O}$ & 4.26 & 4.48 & 4.43 & 4.93 & 3.71 & $\mathrm{Cu}$ & 6.89 & 5.19 & 2.68 & 33.10 & 24.35 & U & 2.16 & 2.05 & 2.45 & 1.83 & 1.67 \\
\hline $\mathrm{P}_{2} \mathrm{O}_{5}$ & 0.01 & 0.01 & 0.01 & 0.01 & 0.09 & $\mathrm{Zn}$ & 55.10 & 42.70 & 68.60 & 30.44 & 52.59 & $\mathrm{La}$ & 35.20 & 43.20 & 43.40 & 20.29 & 53.53 \\
\hline LOI & 0.45 & 0.44 & 0.38 & 0.23 & 1.68 & $\mathrm{Ga}$ & 16.90 & 17.20 & 18.30 & 18.20 & 21.40 & $\mathrm{Ce}$ & 70.70 & 87.10 & 84.60 & 45.50 & 99.66 \\
\hline Total & 98.69 & 98.35 & 99.09 & 99.50 & 99.51 & Ge & 1.25 & 1.40 & 1.52 & 2.09 & 1.65 & $\operatorname{Pr}$ & 8.07 & 9.75 & 9.87 & 6.14 & 11.64 \\
\hline $\mathrm{Na}_{2} \mathrm{O}+\mathrm{K}_{2} \mathrm{O}$ & 8.35 & 8.38 & 8.50 & 8.63 & 8.14 & As & 8.22 & 8.56 & 8.86 & 0.00 & 0.00 & $\mathrm{Nd}$ & 29.00 & 34.90 & 34.90 & 23.71 & 43.14 \\
\hline $\mathrm{Na}_{2} \mathrm{O} / \mathrm{K}_{2} \mathrm{O}$ & 0.96 & 0.87 & 0.92 & 0.75 & 1.19 & $\mathrm{Rb}$ & 97.80 & 101.00 & 117.00 & 147.00 & 116.00 & $\mathrm{Sm}$ & 6.32 & 7.50 & 7.84 & 5.39 & 7.41 \\
\hline $\mathrm{Li}$ & 1.30 & 1.15 & 1.65 & 0.00 & 0.00 & $\mathrm{Sr}$ & 18.80 & 19.50 & 10.40 & 50.24 & 116.60 & $\mathrm{Eu}$ & 0.25 & 0.27 & 0.28 & 0.91 & 1.69 \\
\hline $\mathrm{Be}$ & 4.17 & 3.79 & 4.90 & 0.00 & 0.00 & Y & 42.18 & 54.10 & 59.07 & 38.54 & 43.26 & $\mathrm{Gd}$ & 5.69 & 6.61 & 6.66 & 5.03 & 6.83 \\
\hline Sc & 3.94 & 4.37 & 4.17 & 4.26 & 6.55 & $\mathrm{Zr}$ & 230.00 & 212.00 & 216.00 & 210.10 & 178.10 & $\mathrm{~Tb}$ & 1.20 & 1.39 & 1.45 & 0.92 & 1.10 \\
\hline V & 1.35 & 0.72 & 2.18 & 6.42 & 30.27 & $\mathrm{Nb}$ & 18.90 & 19.60 & 22.30 & 14.70 & 11.38 & Dy & 7.69 & 9.04 & 9.30 & 5.61 & 6.28 \\
\hline $\mathrm{Cr}$ & 12.30 & 18.70 & 6.98 & 307.50 & 213.10 & Mo & 6.39 & 3.86 & 2.66 & 0.00 & 0.00 & Ho & 1.75 & 2.13 & 2.22 & 1.21 & 1.29 \\
\hline Co & 0.91 & 0.82 & 0.62 & 2.81 & 4.28 & $\mathrm{Ag}$ & 0.46 & 0.41 & 0.48 & 0.00 & 0.00 & $\mathrm{Er}$ & 4.99 & 6.24 & 6.53 & 3.52 & 3.50 \\
\hline $\mathrm{Ni}$ & 5.92 & 7.84 & 3.22 & 20.96 & 14.73 & $\mathrm{Cd}$ & 0.18 & 0.17 & 0.19 & 0.00 & 0.00 & $\mathrm{Tm}$ & 0.78 & 1.01 & 1.05 & 0.54 & 0.50 \\
\hline $\mathrm{Cu}$ & 6.89 & 5.19 & 2.68 & 33.10 & 24.35 & In & 0.06 & 0.06 & 0.07 & 0.00 & 0.00 & $\mathrm{Yb}$ & 5.19 & 6.79 & 7.29 & 3.64 & 3.28 \\
\hline $\mathrm{Zn}$ & 55.10 & 42.70 & 68.60 & 30.44 & 52.59 & Sn & 2.84 & 3.25 & 3.63 & 0.00 & 0.00 & Lu & 0.72 & 0.96 & 1.04 & 0.56 & 0.52 \\
\hline Ga & 16.90 & 17.20 & 18.30 & 18.20 & 21.40 & $\mathrm{Sb}$ & 0.63 & 0.65 & 1.77 & 0.00 & 0.00 & TREE & 177.55 & 216.89 & 216.43 & 122.97 & 240.37 \\
\hline $\mathrm{Ge}$ & 1.25 & 1.40 & 1.52 & 2.09 & 1.65 & Cs & 0.45 & 0.45 & 0.96 & 1.04 & 2.64 & LREE/HREE & 5.34 & 5.35 & 5.09 & 4.85 & 9.32 \\
\hline
\end{tabular}



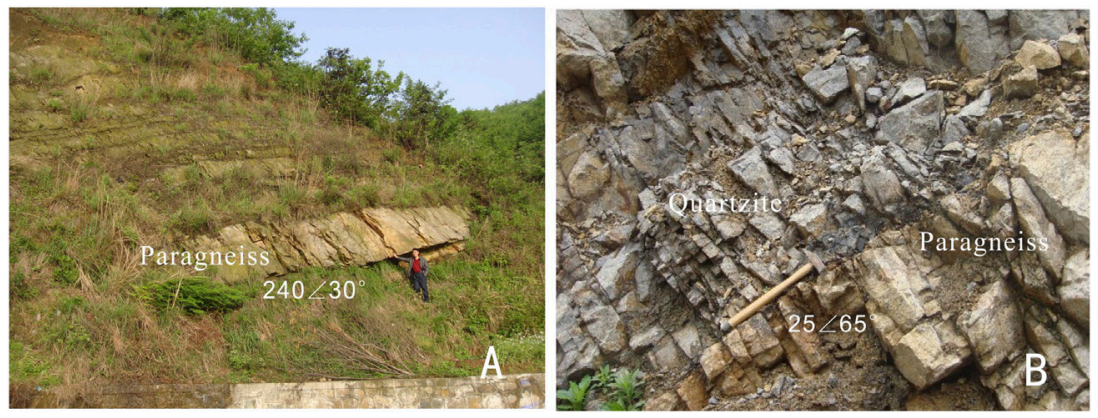

FIGURE 2 | Outcrops of paragneiss in the north of Xinxian county (A) and in the Xinxian Qianhe quarry (B)

collected from the quarry ( $31^{\circ} 41.551^{\prime}$, E $\left.114^{\circ} 56.921^{\prime}\right)$ located on the east side of the road to the south of Qianhe village. Samples XX4-1 and XX4-2 were collected from a hill behind the coach station in the north of Xinxian county (N $31^{\circ} 41.329^{\prime}$, E $114^{\circ} 54.262^{\prime}$ ) (Figure 2). These rocks are off-white and medium to fine-grained and have black and white strips. They are composed of potassium feldspar, plagioclase, quartz, biotite, etc. Samples XX4-1 and XX4-2 were obtained from thick-layered and thin-layered paragneiss, respectively.

\section{ANALYTICAL METHODS}

\section{Petrochemical Analysis}

Petrochemical tests were conducted on 5 samples from Qianhe and the north of Xinxian county for major and trace elements analyses. Experiments were carried out at the State Key Laboratory of Isotope Geochemistry, Guangzhou Institute of Geochemistry, Chinese Academy of Sciences. Major elements were determined by the Varian Vista-PRO ICP-AES (CCD full-spectrum direct reading ICP-AES), with an analytical error (RSD) of less than $5 \%$. Detailed procedures can be found in (Goto and Tatsumi, 1994). Trace elements were determined by the PE-Elan 6000 ICP-MS in the ultra-purification laboratory of the Guangzhou Institute of Geochemistry, Chinese Academy of Sciences, with a RSD of less than 10\%. Detailed procedures can be found in (Liu et al., 1996).

\section{Zircon U-Pb Dating}

Zircon samples were processed before $\mathrm{U}-\mathrm{Pb}$ dating to get rid of mixtures. First, $c a .500 \mathrm{~g}$ of rock sample was weighed out and crushed into $1 \mathrm{~cm}^{3}$ grains. Then these grains were put into a $20 \mathrm{~cm}$-size stainless steel bowl and were ground repetitively for 3-5 s each time in an XZW100 vibrating mill until they were broken into 60 mesh. Dust was removed and an aluminum-made batea was used to concentrate heavy minerals. Then through magnetic and electromagnetic processing, magnetic minerals were removed and refined zircon was obtained. Finally, zircon grains with good crystals were hand picked under binocular for dating (Zhang et al., 2004).

LA-ICP-MS zircon U-Pb dating was conducted at the Key Laboratory of Isotope Geochronology and Geochemistry, Guangzhou Institute of Geochemistry, Chinese Academy of Sciences. Zircon grains were fixed by epoxy resin and made into laser ablation sample targets. The sample targets were ground and polished until the central surface of the zircon was exposed. Carbon dust was sprayed on zircon for CL imaging and then was wiped off for LA-ICP-MS U-Pb analysis (single spot laser ablation was used with a diameter of the laser spot of $31 \mu \mathrm{m}$ and at a firing frequency of $8 \mathrm{~Hz}$ ). Detailed analytical procedures can be found in (Tu et al., 2011). ${ }^{204} \mathrm{~Pb}$ data were used to correct $\mathrm{Pb}$ data in zircon. The errors of single data points were within $1 \sigma$. The ${ }^{206} \mathrm{~Pb} /{ }^{238} \mathrm{U}$ age was obtained, whose weighted averages were at the $95 \%$ confidence level. Experimental results were plotted into concordia diagrams using the software of Isoplot 3.0 (Ludwig, 2012).

\section{EXPERIMENTAL RESULTS}

\section{Characteristics of Major Elements}

As shown in Table 1, results were obtained through the geochemical analysis of major elements. It can be seen that the paragneiss in the Qianhe area has a high content of silicon $\left(\mathrm{SiO}_{2}=76.10-76.42 \%\right)$, aluminum $\left(\mathrm{Al}_{2} \mathrm{O}_{3}=11.58-11.91 \%\right)$, and alkali elements $\left(\mathrm{Na}_{2} \mathrm{O}+\mathrm{K}_{2} \mathrm{O}=8.35-8.50 \%\right)$ but shows a deficiency in titanium $\left(\mathrm{TiO}_{2}=0.09-0.10 \%\right)$ and calcium $(\mathrm{CaO}=0.13-0.26 \%)$. Its potassium content is comparatively high $\left(\mathrm{Na}_{2} \mathrm{O} / \mathrm{K}_{2} \mathrm{O}=0.57-0.76\right)$ and Aluminous Saturation Index $(\mathrm{A} / \mathrm{CNK})$ is in the range of $1.35-1.38$, suggesting that the rock is peraluminous.

The paragneiss in the north of Xinxian county is consistent with the one in the Qianhe area in terms of chemical composition, as it is rich in silicon $\left(\mathrm{SiO}_{2}=68.29-75.93 \%\right)$, aluminum $\left(\mathrm{Al}_{2} \mathrm{O}_{3}=\right.$ $12.58-16.06 \%)$ and alkali elements $\left(\mathrm{Na}_{2} \mathrm{O}+\mathrm{K}_{2} \mathrm{O}=8.14-8.63 \%\right)$ but poor in titanium and calcium $(\mathrm{CaO}=0.14-0.53 \%)$. By comparison, its content of potassium $\left(\mathrm{Na}_{2} \mathrm{O} / \mathrm{K}_{2} \mathrm{O}=0.79-1.19\right)$ is lower than that of the paragneiss in the Qianhe area. As the $\mathrm{A} / \mathrm{CNK}$ is in the range of $1.43-1.85$, it is evident that the rock is peraluminous.

\section{Characteristics of Trace and Rare Earth Elements}

The results of trace element analysis are shown in Table 1. The total amount of REE was high in the Qianhe paragneiss (QH-1, 
TABLE 2 | Zircon LA ICP MS U-Pb age data of Qianhe and Chengbei paragneisses in Xinxian.

\begin{tabular}{|c|c|c|c|c|c|c|c|c|c|}
\hline No. & Sample & $\mathbf{P b}$ & Th & $\mathbf{U}$ & Th/U & $207 \mathrm{~Pb} / 206 \mathrm{~Pb}$ & $207 \mathrm{~Pb} / 235 \mathrm{U}$ & $206 \mathrm{~Pb} / 238 \mathrm{U}$ & $206 \mathrm{~Pb} / 238 \mathrm{U}$ \\
\hline 1 & $\mathrm{QH}-1-01$ & 40 & 210 & 229 & 0.92 & $0.0714 \pm 37$ & $1.1861 \pm 662$ & $0.1195 \pm 20$ & $727.7 \pm 11.4$ \\
\hline 2 & $\mathrm{QH}-1-02$ & 51 & 276 & 270 & 1.02 & $0.0664 \pm 24$ & $1.2130 \pm 495$ & $0.1311 \pm 22$ & $793.9 \pm 12.6$ \\
\hline 3 & $\mathrm{QH}-1-03$ & 99 & 139 & 2381 & 0.06 & $0.0764 \pm 25$ & $0.3534 \pm 119$ & $0.0334 \pm 4$ & $211.5 \pm 2.3$ \\
\hline 4 & $\mathrm{QH}-1-04$ & 69 & 145 & 1536 & 0.09 & $0.0732 \pm 27$ & $0.3682 \pm 147$ & $0.0361 \pm 5$ & $228.6 \pm 3.0$ \\
\hline 5 & $\mathrm{QH}-1-05$ & 106 & 235 & 1941 & 0.12 & $0.0702 \pm 21$ & $0.4249 \pm 128$ & $0.0436 \pm 6$ & $275.0 \pm 3.5$ \\
\hline 6 & $\mathrm{QH}-1-06$ & 50 & 253 & 274 & 0.92 & $0.0639 \pm 25$ & $1.1170 \pm 436$ & $0.1261 \pm 27$ & $765.9 \pm 15.3$ \\
\hline 7 & $\mathrm{QH}-1-07$ & 59 & 222 & 297 & 0.75 & $0.1149 \pm 57$ & $1.9402 \pm 899$ & $0.1222 \pm 16$ & $743.4 \pm 9.1$ \\
\hline 8 & $\mathrm{QH}-1-08$ & 28 & 113 & 156 & 0.72 & $0.0606 \pm 23$ & $1.1113 \pm 447$ & $0.1324 \pm 22$ & $801.6 \pm 12.7$ \\
\hline 9 & $\mathrm{QH}-1-09$ & 103 & 753 & 2008 & 0.37 & $0.0920 \pm 35$ & $0.4554 \pm 174$ & $0.0358 \pm 6$ & $227.0 \pm 3.9$ \\
\hline 10 & $\mathrm{QH}-1-10$ & 128 & 324 & 2348 & 0.14 & $0.0814 \pm 31$ & $0.4535 \pm 206$ & $0.0398 \pm 8$ & $251.7 \pm 5.1$ \\
\hline 11 & QH1A-01 & 63 & 341 & 357 & 0.95 & $0.0628 \pm 30$ & $1.1044 \pm 530$ & $0.1261 \pm 20$ & $765.4 \pm 11.3$ \\
\hline 12 & QH1A-02 & 39 & 211 & 221 & 0.96 & $0.0665 \pm 38$ & $1.1492 \pm 657$ & $0.1237 \pm 21$ & $752.1 \pm 12.0$ \\
\hline 13 & QH1A-03 & 45 & 252 & 252 & 1 & $0.0603 \pm 39$ & $1.1180 \pm 707$ & $0.1328 \pm 24$ & $803.8 \pm 13.9$ \\
\hline 14 & $\mathrm{QH} 1 \mathrm{~A}-04$ & 60 & 355 & 354 & 1 & $0.0608 \pm 39$ & $1.0201 \pm 639$ & $0.1189 \pm 20$ & $724.4 \pm 11.7$ \\
\hline 15 & QH1A-05 & 76 & 481 & 429 & 1.12 & $0.0639 \pm 45$ & $1.1445 \pm 786$ & $0.1266 \pm 24$ & $768.7 \pm 13.8$ \\
\hline 16 & QH1A-06 & 60 & 314 & 333 & 0.94 & $0.0622 \pm 50$ & $1.1760 \pm 915$ & $0.1332 \pm 28$ & $805.9 \pm 15.9$ \\
\hline 17 & QH1A-07 & 35 & 173 & 214 & 0.81 & $0.0621 \pm 51$ & $1.1070 \pm 858$ & $0.1259 \pm 30$ & $764.6 \pm 17.2$ \\
\hline 18 & $\mathrm{QH} 1 \mathrm{~A}-08$ & 52 & 315 & 306 & 1.03 & $0.0633 \pm 48$ & $1.1247 \pm 830$ & $0.1236 \pm 27$ & $751.1 \pm 15.4$ \\
\hline 19 & QH1A-09 & 127 & 271 & 358 & 0.76 & $0.1749 \pm 308$ & $6.9620 \pm 2.0643$ & $0.1523 \pm 190$ & $913.6 \pm 106.5$ \\
\hline 20 & QH1A-10 & 32 & 42 & 532 & 0.08 & $0.0810 \pm 120$ & $0.8841 \pm 2528$ & $0.0563 \pm 40$ & $352.9 \pm 24.6$ \\
\hline 21 & QH1A-11 & 60 & 352 & 312 & 1.13 & $0.0646 \pm 55$ & $1.2665 \pm 1035$ & $0.1337 \pm 26$ & $809.1 \pm 14.9$ \\
\hline 22 & QH1A-12 & 49 & 276 & 258 & 1.07 & $0.0615 \pm 61$ & $1.2061 \pm 1155$ & $0.1327 \pm 31$ & $803.0 \pm 17.4$ \\
\hline 23 & $\mathrm{QH} 1 \mathrm{~A}-13$ & 27 & 118 & 157 & 0.75 & $0.0597 \pm 55$ & $1.0881 \pm 981$ & $0.1233 \pm 28$ & $749.5 \pm 16.3$ \\
\hline 24 & $\mathrm{QH} 1 \mathrm{~A}-14$ & 53 & 309 & 295 & 1.05 & $0.0563 \pm 43$ & $1.0710 \pm 796$ & $0.1294 \pm 27$ & $784.3 \pm 15.6$ \\
\hline 25 & QH1A-15 & 42 & 227 & 271 & 0.84 & $0.0548 \pm 44$ & $0.8942 \pm 675$ & $0.1119 \pm 24$ & $684.0 \pm 14.0$ \\
\hline 26 & $\mathrm{QH} 1 \mathrm{~A}-16$ & 29 & 141 & 161 & 0.87 & $0.0490 \pm 44$ & $0.9469 \pm 795$ & $0.1342 \pm 31$ & $811.9 \pm 17.7$ \\
\hline 27 & QH1A-17 & 38 & 193 & 209 & 0.92 & $0.0478 \pm 40$ & $0.9223 \pm 719$ & $0.1332 \pm 27$ & $806.0 \pm 15.6$ \\
\hline 28 & QH1A-18 & 49 & 241 & 278 & 0.87 & $0.0529 \pm 45$ & $0.9714 \pm 789$ & $0.1268 \pm 32$ & $769.5 \pm 18.1$ \\
\hline 1 & $X \times 4-1-1$ & 34.9 & 329 & 230 & 1.43 & $0.0781 \pm 84$ & $1.0141 \pm 1135$ & $0.0914 \pm 21$ & $564.0 \pm 12.6$ \\
\hline 2 & $x \times 4-1-2$ & 12.7 & 80 & 77 & 1.04 & $0.1279 \pm 157$ & $1.5972 \pm 1976$ & $0.0861 \pm 27$ & $532.7 \pm 15.8$ \\
\hline 3 & $x \times 4-1-3$ & 10.8 & 92 & 49 & 1.88 & $0.0589 \pm 79$ & $1.1037 \pm 1517$ & $0.1338 \pm 43$ & $809.7 \pm 24.5$ \\
\hline 4 & $x \times 4-1-4$ & 30 & 115 & 570 & 0.2 & $0.0541 \pm 66$ & $0.3111 \pm 369$ & $0.0406 \pm 11$ & $256.3 \pm 7.1$ \\
\hline 5 & $x \times 4-1-5$ & 12.6 & 78 & 35 & 2.26 & $0.2597 \pm 331$ & $5.8428 \pm 9430$ & $0.1471 \pm 102$ & $884.5 \pm 57.4$ \\
\hline 6 & $x \times 4-1-6$ & 7.3 & 87 & 27 & 3.28 & $0.0829 \pm 114$ & $1.4493 \pm 1909$ & $0.1276 \pm 56$ & $774.4 \pm 32.1$ \\
\hline 7 & $x \times 4-1-7$ & 50.7 & 1029 & 366 & 2.81 & $0.0595 \pm 62$ & $0.6289 \pm 605$ & $0.0734 \pm 21$ & $456.8 \pm 12.9$ \\
\hline 8 & $x \times 4-1-8$ & 36.5 & 195 & 227 & 0.86 & $0.0444 \pm 46$ & $0.7755 \pm 755$ & $0.1181 \pm 39$ & $719.7 \pm 22.7$ \\
\hline 9 & $x \times 4-1-9$ & 38.1 & 59 & 52 & 1.14 & $0.2620 \pm 372$ & $17.1777 \pm 2.9396$ & $0.3072 \pm 336$ & $1727.1 \pm 165.8$ \\
\hline 10 & $X \times 4-1-10$ & 13.5 & 73 & 106 & 0.69 & $0.0319 \pm 47$ & $0.5059 \pm 808$ & $0.1063 \pm 56$ & $651.4 \pm 32.6$ \\
\hline 11 & $X \times 4-1-11$ & 21.8 & 116 & 114 & 1.01 & $0.0492 \pm 59$ & $0.8956 \pm 1072$ & $0.1235 \pm 41$ & $750.7 \pm 23.5$ \\
\hline 12 & $X \times 4-1-12$ & 20.8 & 593 & 83 & 7.15 & $0,1119 \pm 171$ & $1.7061 \pm 4296$ & $0.1011 \pm 77$ & $620.8 \pm 45.2$ \\
\hline 13 & $x \times 4-1-13$ & 18.8 & 89 & 106 & 0.84 & $0.0536 \pm 73$ & $0.9852 \pm 1320$ & $0.1278 \pm 36$ & $775.1 \pm 20.8$ \\
\hline 14 & $x \times 4-1-14$ & 183.5 & 346 & 605 & 0.57 & $0.1024 \pm 130$ & $3.6523 \pm 4709$ & $0.2446 \pm 77$ & $1410.5 \pm 40.0$ \\
\hline 1 & $x \times 4-2-3$ & 12 & 125 & 52 & 2.41 & $0.0659 \pm 87$ & $1.0539 \pm 1352$ & $0.1207 \pm 39$ & $734.8 \pm 22.3$ \\
\hline 2 & $x \times 4-2-4$ & 19.3 & 173 & 100 & 1.72 & $0.0915 \pm 103$ & $1.3240 \pm 1624$ & $0.1032 \pm 30$ & $633.4 \pm 17.7$ \\
\hline 3 & $x \times 4-2-5$ & 16.1 & 138 & 90 & 1.53 & $0.0639 \pm 72$ & $0.9180 \pm 982$ & $0.1078 \pm 33$ & $660.2 \pm 18.9$ \\
\hline 4 & $x \times 4-2-6$ & 21.5 & 209 & 130 & 1.61 & $0.0496 \pm 69$ & $0.6700 \pm 907$ & $0.0966 \pm 29$ & $594.5 \pm 17.3$ \\
\hline 5 & $x \times 4-2-7$ & 14.9 & 105 & 75 & 1.4 & $0.0830 \pm 90$ & $1.4476 \pm 1451$ & $0.1289 \pm 45$ & $781.6 \pm 25.5$ \\
\hline 6 & $x \times 4-2-8$ & 11.7 & 93 & 62 & 1.49 & $0.0647 \pm 86$ & $1.0191 \pm 1356$ & $0.1156 \pm 36$ & $705.4 \pm 20.8$ \\
\hline 7 & $x \times 4-2-9$ & 8.1 & 72 & 41 & 1.74 & $0.0734 \pm 137$ & $1.1542 \pm 1995$ & $0.1171 \pm 44$ & $713.8 \pm 25.5$ \\
\hline 8 & $x \times 4-2-10$ & 16.1 & 136 & 74 & 1.84 & $0.0845 \pm 102$ & $1.3956 \pm 1534$ & $0.1208 \pm 35$ & $735.1 \pm 20.2$ \\
\hline 9 & $X \times 4-2-11$ & 11.9 & 64 & 68 & 0.94 & $0.0561 \pm 121$ & $0.9941 \pm 1955$ & $0.1276 \pm 59$ & $774.1 \pm 33.7$ \\
\hline 10 & $x \times 4-2-12$ & 22.2 & 224 & 104 & 2.16 & $0.0667 \pm 217$ & $1.1527 \pm 3379$ & $0.1229 \pm 87$ & $747.4 \pm 50.1$ \\
\hline 11 & $x \times 4-2-13$ & 10 & 81 & 45 & 1.82 & $0.0879 \pm 395$ & $1.6321 \pm 6640$ & $0.1293 \pm 12$ & $783.7 \pm 73.0$ \\
\hline 12 & $x \times 4-2-14$ & 14.1 & 73 & 53 & 1.39 & $0.2033 \pm 1171$ & $5.3510 \pm 2.7974$ & $0.1599 \pm 208$ & $956.0 \pm 115.8$ \\
\hline
\end{tabular}

$\mathrm{QH}-2$, and $\mathrm{QH}-3)$, up to $117.55-216.89 \mu \mathrm{g} / \mathrm{g}$. As shown in the chondrite-normalized REE diagram (Figure 3), LREEs were enriched as $\mathrm{La} / \mathrm{Yb}$ was between 4.27 and 4.86 and the negative $\mathrm{Eu}$ anomaly was evident ( $\delta \mathrm{Eu}$ is $0.12-0.13$ ) (Sun and McDonough, 1989). Besides, its pattern curve was skewed to the right and had an obvious $\mathrm{V}$ valley. As shown in the primitive mantle-normalized trace element spider diagram (Figure 4), elements such as $\mathrm{Rb}, \mathrm{K}, \mathrm{Th}$, and $\mathrm{U}$ were enriched in the paragneiss in the Qianhe area whereas elements such as $\mathrm{Ba}$, $\mathrm{Nb}, \mathrm{Sr}$, and Ti were depleted.

The total amount of REEs was also high in the Xinxian paragneiss (XX4-1, XX4-2), up to 122.97-240.37 $\mu \mathrm{g} / \mathrm{g}$. Its chondrite-normalized REE plot was similar to that of the paragneiss of the Qianhe area; however, the content of heavy 


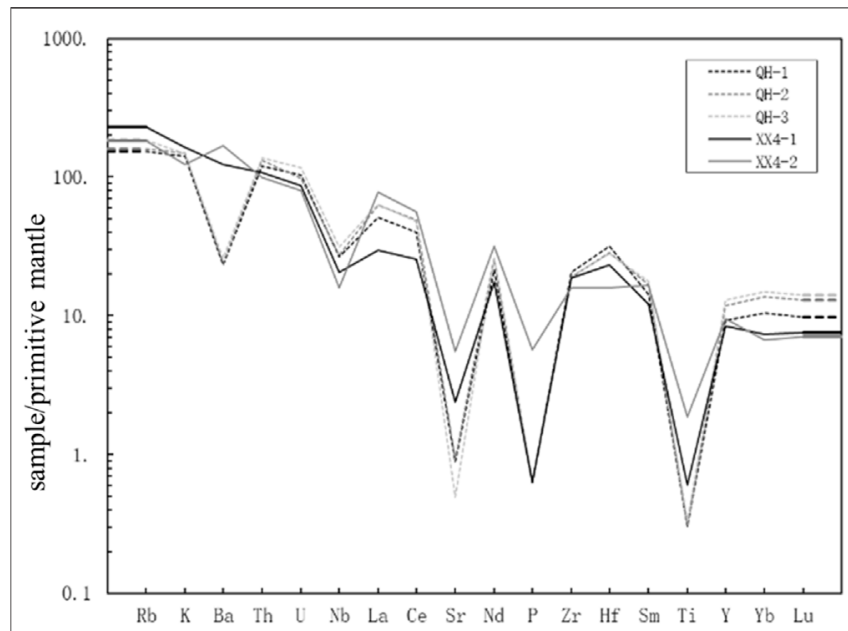

FIGURE 3| Primitive mantle-normalized trace-elements spider diagram.

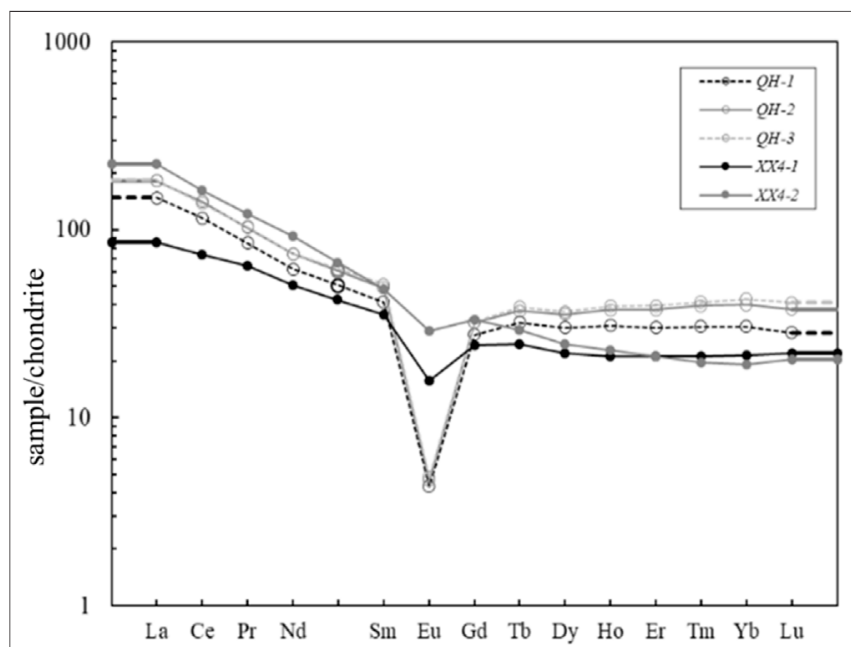

FIGURE 4 | Chondrite-normalized REE plot of paragneiss.

rare Earth elements (HREE) was higher with $\mathrm{La} / \mathrm{Yb}$ in the range of 4.00-11.71. Besides, the negative Eu anomaly was relatively indistinct with $\delta \mathrm{Eu}$ of $0.53-0.73$. As shown in the spider diagram (Figure 4), elements such as $\mathrm{Rb}, \mathrm{K}, \mathrm{Ba}$, Th, and $\mathrm{U}$ were enriched in the paragneiss in the north of Xinxian county whereas elements such as $\mathrm{Nb}, \mathrm{Sr}$, and $\mathrm{Ti}$ were depleted.

\section{Results of Zircon Dating}

Zircon U-Pb dating was conducted on Samples QH-1 and QH-1A from the Qianhe area and Samples XX4-1 and XX4-2 from the north of Xixian county. The CL image (Figure 5) shows that zircon grains were of similar sizes with a length to width ratio of about 1:2. All zircons contained detrital zircon and most of them had a clear core-edge double structure. Detrital zircon in the core of zircons had oscillatory zoning. For most zircons, the edge was darker than the core (Table 2).
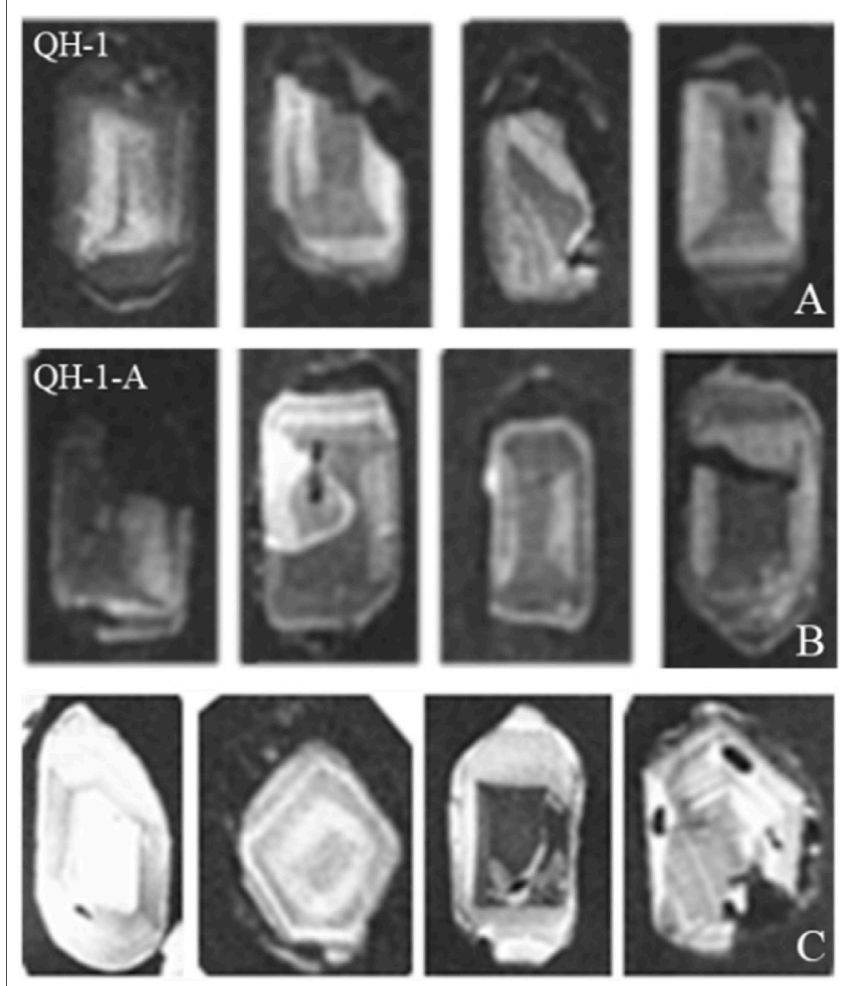

FIGURE 5 | CL images of zircon in paragneiss ((A) Qianhe QH-1 sample,

(B) Qianhe QH-1-A sample, (C) XX4-1 thick-layered paragneiss sample and XX4-2 thin-layered paragneiss sample from the north of Xinxian county).

Five points on the detrital zircon of the metamorphic composite zircon sample QH-1 were selected for the determination of $\mathrm{Th}$ and $\mathrm{U}$ concentrations (Figure 5A). The ratio of $\mathrm{Th} / \mathrm{U}$ suggests that these zircons were formed during the Proterozoic at the ages of 801, 793, 756, 743, and $727 \mathrm{Ma}$, respectively. Five points on the edge of the metamorphic composite zircon were dated at 251,228, 226, and $211 \mathrm{Ma}$, respectively (Figure 6).

A total of 17 points on the detrital zircon of the metamorphic composite zircon sample QH-1-A were selected for the determination of $\mathrm{Th}$ and $U$ concentrations (Figure 5B). Four age ranges were obtained: $913,811-803,784-724$, and $684 \mathrm{Ma}$. One point on the edge of the metamorphic zircon was dated at $352 \mathrm{Ma}$.

A total of 24 points on the detrital zircon of Xinxian metamorphic composite zircon samples were selected for the determination of Th and $U$ concentrations (Figure 5C). These points have a wide age range: $456-1,727 \mathrm{Ma}$. One point on the edge of the metamorphic zircon was dated at $256 \mathrm{Ma}$.

$\mathrm{U}-\mathrm{Pb}$ dating results for the edge of the metamorphic zircon and the metamorphic composite zircon were more concentrated, with ages ranging from 211 to $352 \mathrm{Ma}$ and concordant ages of $233 \pm 24 \mathrm{Ma}$. Besides, the $\mathrm{Th} / \mathrm{U}$ ratios of these seven points are in the range of $0.08-0.37$ while three of them are below 0.1 , significantly smaller than the $\mathrm{Th} / \mathrm{U}$ ratio of magmatic zircon (generally greater than 0.4 ) and closer to that of metamorphic 

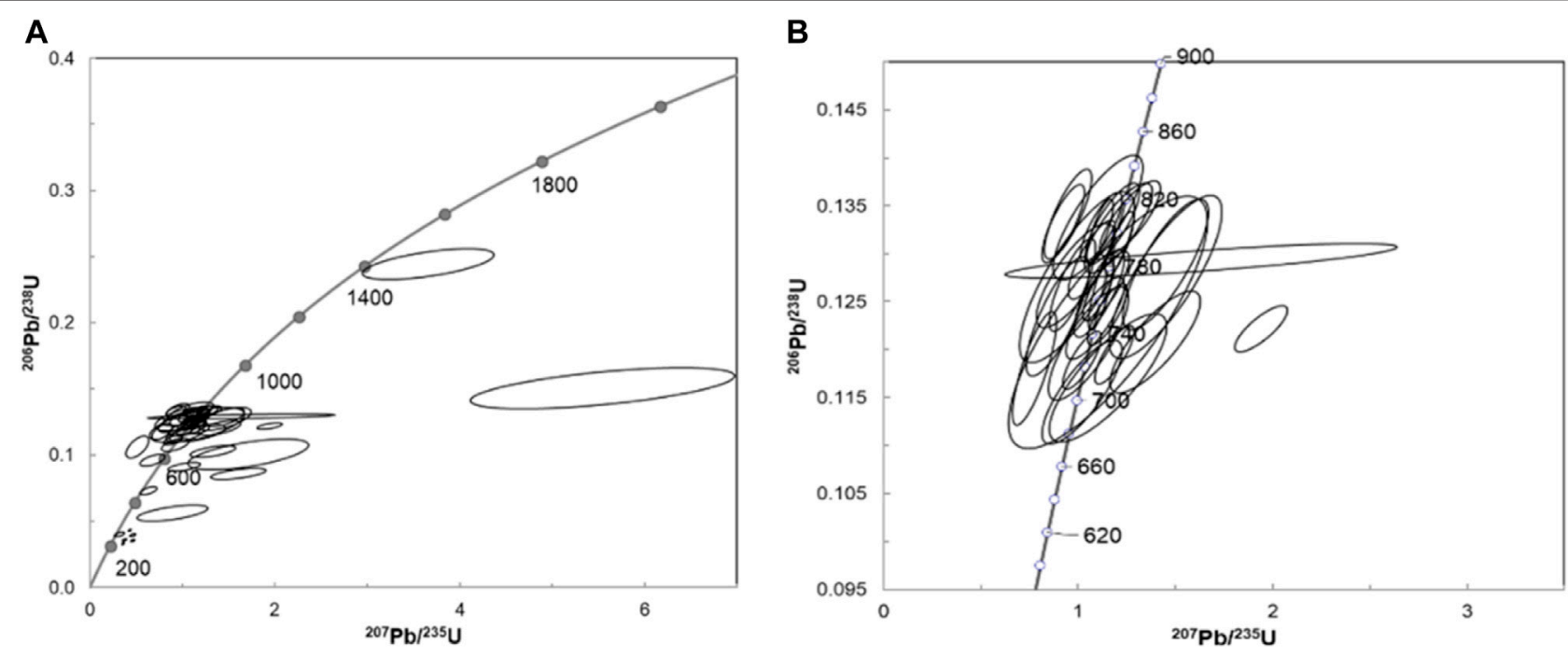

FIGURE 6 | Zircon U-Pb concordia diagram for paragneisses (A); zircon U-Pb concordant ages in the range of 705-811 Ma (B).

zircon (Bryant et al., 2002). As suggested by the U-Pb dating results, the detrital zircons in the samples were mainly formed during the Neoproterozoic (564-884 Ma), with their ages mainly in the range of 705-811 Ma. However, some detrital zircons were formed in the Paleozoic and Middle Proterozoic as shown by dating results.

\section{DISCUSSION}

\section{Analysis of Zircon U-Pb Dating Results}

Two results were obtained from zircon $\mathrm{U}-\mathrm{Pb}$ dating. The first one was about the edge of metamorphic zircon, whose age was in the range of 211-352 Ma and concordant age was $233 \pm 24 \mathrm{Ma}$. The other result was about detrital zircon in metamorphic zircon, whose age ranged from 456 to $1,727 \mathrm{Ma}$, mostly between 705 and $811 \mathrm{Ma}$.

The edge of the metamorphic zircon in samples was dated to the Triassic, suggesting that paragneiss in Xinxian county experienced high-pressure metamorphism during the Triassic. It was consistent with a large amount of previous research on the metamorphic age of the Dabie-Sulu UHP metamorphic belt which confined the age to the Triassic. Hacker et al. (1998) suggested that the metamorphism of the Dabie-Sulu UHP metamorphic belt reached its peak at $245 \mathrm{Ma}$ through zircon dating for paragneiss. Liu et al. (2006) found through U-Pb dating for the edge of metamorphic zircon with coesite that the metamorphic event of the Dabie-Sulu UHP metamorphic belt took place during 240-225 Ma. Our work suggests that the edge of metamorphic zircon is consistent with the data reported by previous researchers, providing further evidence that paragneiss in Xinxian county experienced ultrahigh-pressure metamorphic events during the Triassic.

The dating results of detrital zircon showed that many samples were dated to the middle of the Neoproterozoic, which accounted for about $72 \%$ of the total number of samples. Their age range of $700-800 \mathrm{Ma}$ was consistent with the characteristic zircon age of rocks in the Yangtze block (Rowley et al., 1997; Hacker et al., 1998). Considering no large-scale magmatic activity was recorded in the Middle Neoproterozoic in the North China craton, the protolith of the paragneiss in Xinxian county was hence supposed to originate from the Yangtze block. As the magmatic activity was caused by the breakdown of the Rodinia supercontinent, the protolith of the paragneiss of Xinxian county may contain granite formed in the Middle Neoproterozoic in the Yangtze block. In addition, part of detrital zircon in Sample XX4-2 was dated to the Paleozoic (456-532 Ma), which was consistent with data obtained by previous researches of the paragneiss of the UHP belt (Hacker et al., 1998; Liu et al., 2004). However, such age data were in small amount in previous researches and were considered to be the result of the loss of $\mathrm{Pb}$, or due to the fact that the core and edge of zircon were not separated. Hence, these data were not widely discussed or constraining the age by the fugacity state of the paragneiss and orthogneiss (Fu-lai and Xue, 2007). Additionally, (Yuan et al., 2015) found that the core of metamorphic zircon in paragneiss in Luotian of Hubei province was mostly dated to the Paleozoic. No signs of $\mathrm{Pb}$ loss could be found, and the boundary between the margin and core was also clear on CL images. Further, considering parts of zircon were dated to the Paleozoic in our work and they had the $\mathrm{Th} / \mathrm{U}$ ratio close to the ratio range of zircon of magmatic origin (Dao-gong et al., 2001), part of the protolith of the paragneiss was supposed to form later than $456 \mathrm{Ma}$. As some detrital zircon in the samples was dated to the Middle Proterozoic, the source material of the protolith could possibly come from the crustal residual of the Middle Proterozoic in the Yangtze block rather than from the Paleozoic sedimentary cover. 


\section{Protolith Analysis}

With regard to the protolith of the paragneiss of the Dabie-Sulu UHP metamorphic belt, it was considered in previous research to be mainly granite formed by the magma coming from the Rodinia rift in the Neoproterozoic at the north edge of the Yangtze block (Zheng et al., 2003). Based on geochemical analysis of the paragneiss in the Dabie belt and Cretaceous granite, the source materials were likely to come from the north edge of the subducting Yangtze block (Frost and Frost, 2011). Therefore, some researchers proposed that the paragneiss in the Dabie belt and Cretaceous granite were produced at different horizons of the Yangtze block (Shu-guang et al., 1997).

The samples of paragneiss from Xinxian had a high $\mathrm{SiO}_{2}$ content, up to $68.29-76.42 \%$, and their $\mathrm{A} / \mathrm{CNK}$ reached $1.35-1.85$, indicating they are peraluminous. The alkali content ranged between 8.14 and $8.63 \%$, in which the content of potassium is relatively high as the ratio of $\mathrm{Na}_{2} \mathrm{O} / \mathrm{K}_{2} \mathrm{O}$ is between 0.57 and 1.19. The content of calcium was low and in the range of $0.13-0.53 \%$ (Wong et al., 2009; Frost and Frost, 2011). Light rare Earth elements (LREEs) were enriched in the samples and negative Eu anomaly was distinct. Elements such as $\mathrm{Rb}, \mathrm{K}, \mathrm{Th}$, and $\mathrm{U}$ were enriched whereas elements such as $\mathrm{Nb}, \mathrm{Sr}$, and Ti were depleted. This distribution pattern suggests that the protolith was formed by the materials of the continental crust (Chen et al., 2006). Felsic magma generated by partial melting of felsic rock under high pressure can extract $\mathrm{Si}, \mathrm{K}, \mathrm{Na}$, LILEs, and LREEs (Hermann and Green, 2001), and hence, the magma can become enriched in silicon, alkali, aluminum and LREEs while depleted in calcium and magnesium and iron. As Gu found LILEs and LREEs were depleted in eclogite ( $\mathrm{Gu}$ et al., 2013), it suggests that the paragneiss in Xinxian county might be partially melted, like the felsic magma formed under high pressure. The continuous process from sub-solidus dehydration to partial melting within the UHP gneissic rocks is also evidenced by experimental and petrological observations in Shuanghe paragneiss (Liu and $\mathrm{Wu}, 2013$ ). According to the geochemical characteristics of the samples, the protolith is likely to be sedimentary rock that has been partially melted during the subduction and retreat of the Yangtze block (Wallis et al., 2005).

\section{Tectonic Setting of the Shuanghe UHP Metamorphic Protolith}

By volume, the gneiss occupies between 70 and $80 \%$ of the DabieSulu complex (e.g., Dao-gong et al., 2000; Wang et al., 2000; Huifen et al., 2001). Of these, 40-60\% comprise foliated, garnetbearing, A-type granitic rock (Shu-tian and You, 2005). These rocks are associated with jadeite-quartzites and marbles that formed from quartz sandstone and limestone respectively. According to the zircon $\mathrm{U}-\mathrm{Pb}$ dating results, the protoliths of these rocks are controlled by Paleozoic Dabie - Sulu basin. Distributions of the major-elements of these rocks are high $\mathrm{SiO}_{2}$, alkali-rich, high $\mathrm{Na}_{2} \mathrm{O}$ and low $\mathrm{Al}_{2} \mathrm{O}_{3}$. The mineral component is more rich in alkaline ferromagnesian. The sedimentary origins of these protoliths appear to be neritic facies, some of which are clastic sediments (quartz sandstone to arkoses) and chemical sediments (limestone). These are characteristic of the continental slope environment. The Dabie-Sulu ocean basin was not a mature ocean; it lacked deep-water sedimentation, such as siliceous deposits and turbidites. It evidently lacked contemporaneous pillow lavas and cumulates of ophiolite rock assemblages which is why we have not found remnants of ophiolitic melanges (Wang and Cong Bo-lin, 1998). As the Dabie-Sulu ocean basin was an aborted oceanic basin, it narrowed, with a resultant increase in salinity. This ultimately led to the oceanic basin sediments becoming increasingly alkaline. This provided the necessary material conditions for the formation of alkaline mafic minerals (sodic pyroxenes and amphiboles) during the Late Triassic metamorphism of these rocks.

\section{CONCLUSION}

1) Paragneiss in the Qianhe and Chengbei areas of Xinxian county experienced a metamorphic event during $233 \pm$ $24 \mathrm{Ma}$, suggesting that the rock was formed later than the Permian.

2) Paragneiss in Xixian county is enriched in silicon, alkali, aluminum and LREEs while depleted in calcium, magnesium and iron. Besides, negative $\mathrm{Eu}$ anomalies are evident. It suggests that the protolith may be formed by terrestrial materials.

3) Detrital zircon in paragneiss in the Qianhe area and north of Xinxian county was dated to $456-1727 \mathrm{Ma}$, mainly in the range of 705-811 Ma. It suggests that the protolith should be formed no earlier than $456 \mathrm{Ma}$. And they were generated in the Dabie-Sulu ocean basin or abortive ocean basin in the Paleozoic era.

\section{DATA AVAILABILITY STATEMENT}

The original contributions presented in the study are included in the article/Supplementary Material, further inquiries can be directed to the corresponding authors.

\section{AUTHOR CONTRIBUTIONS}

LY was responsible for most of the experimental analysis and paper writing; $\mathrm{ZY}$ was responsible for sampling and experimental processing; $\mathrm{LZ}$ was responsible for the experimental design and the paper revision.

\section{ACKNOWLEDGMENTS}

Researcher Xianglin Tu, Key Laboratory of Isotope Dating and Geochemistry, Guangzhou Institute of Geochemistry, Chinese Academy of Sciences, and others assisted in U-Pb age determination and provided many valuable comments, and we would like to express our sincere gratitude. 


\section{REFERENCES}

Bryant, D. L., Ayers, J. C., Gao, S., Miller, C. F., and Zhang, H. (2002). "Geochronologic Constraints on the Location of the Sino-Korean/Yangtze Suture and Evolution of the Northern Dabie Shan," in AGU Spring Meeting Abstracts (Boulder: Geological Society of America Bulletin).

Chen, W, Zhao-wen, X, Hong-chao, L, Xiao-nan, Y, Jin-quan, C, Wang, H, et al. (2013). Petrogenesis and Origin of the Xinxian Granitic Batholith in Henan Province and its Implication for the Tectonic Evolution of the Western Dabie Area. Acta Geologica Sinica 87 (10), 1510-1524.

Chen, Y., Ye, K., Liu, J.-B., and Sun, M. (2006). Multistage Metamorphism of the Huangtuling Granulite, Northern Dabie Orogen, Eastern China: Implications for the Tectonometamorphic Evolution of Subducted Lower continental Crust. J. Metamorphic Geology. 24 (7), 633-654. doi:10.1111/j.1525-1314.2006.00659.x

Dao-gong, C., Isachsen, C., Xia-chen, Z., Zhou, T., Chen, H., and Xia, Q. (2000). The Zircons U-Pb Ages of Qianshan Gneiss in Anhui. Chin. Sci. Bull. 45 (02), 214-217. doi:10.1007/BF02886187

Dao-gong, Chen., Bin-xian, Li., Xia, Qun-ke., Wu, Yuan-bao., and Chen, Hao. (2001). An Evaluation of Zircon U-Pb Dating for Metamorphic Rocks and Comments on Zircon Ages of Dabie Orogen. Acta Geologica Sinica 17 (01), 129-138. doi:10.2118/69841-PA

Dong-xing, Z., Guo-min, H., and Shi-wei, Z. (2011). Geochemical Characteristics and Metallogeniss of Early Cretaceous Granites in Western Dabie Orogen and Their Association with Mineralization: Evidence from Tangjiaping Granite Porphyry and Xinxian Batholith. Mineral. Exploration 2 (05), 568-573.

Frost, C. D., and Frost, B. R. (2011). On Ferroan (A-type) Granitoids: Their Compositional Variability and Modes of Origin. J. Petrol. 52 (1), 39-53. doi:10.1093/petrology/egq070

Fu-lai, L., and Xue, H. (2007). Review and prospect of SHRIMP U-Pb Dating on Zircons from Sulu-Dabie UHP Metamorphic Rocks. Acta Petrologica Sinica 23 (11), 2737-2756. doi:10.3969/j.issn.1000-0569.2007.11.006

Goto, A. T., and Tatsumi, Y. O. (1994). Quantitative Analysis of Rock Samples by an X-ray Fluorescence Spectrometer (I). Rigaku J. 11 (1), 40-59. doi:10.1097/ 00024382-199401001-00145

Gu, X, Liu, Y, and Deng, L (2013). Geochronology and Petrogenesis of Eclogite from the Luotian Dome, North Dabie Complex Zone (central China), and Their Element and Isotope Behavior during Exhumation. Chin. Sci. Bull. 58 (22), 2132-2137. doi:10.1360/972013-589

Hacker, B. R., Ratschbacher, L., Webb, L., Ireland, T., Walker, D., and Shuwen, D. (1998). U/Pb Zircon Ages Constrain the Architecture of the Ultrahigh-Pressure Qinling-Dabie Orogen, China[J]. Earth Planet. Sci. Lett. 161 (1-4), 215-230. doi:10.1016/s0012-821x(98)00152-6

Hermann, J., and Green, D. H. (2001). Experimental Constraints on High Pressure Melting in Subducted Crust. Earth Planet. Sci. Lett. 188 (1-2), 149-168. doi:10.1016/s0012-821x(01)00321-1

Hui-fen, X., Yang, T., Fu-lai, L., and Liou, J. G. (2001). Multi Age-Time Evolution of Granite Gneisses-Granite in the Southern Sulu HP-UHP Metamorphic Belt. Acta Geologica Sinica 75 (03), 371-378.

Kun-guang, Y., Xie, J., Liu, Q., She, Z., and Chang-qian, M. (2009). Deformation Characteristics of Foliated Granite and Dating of Zircon in Western Dabie Margin. Sci. China,Ser.D. 39 (04), 464-473. doi:10.1007/s11430-009-0001-7

Liu, F., Liou, J. G., and Xue, H. (2006). Identification of UHP and Non-UHP Orthogneisses in the Sulu UHP Terrane, Eastern China: Evidence from SHRIMP U-Pb Dating of Mineral Inclusion-Bearing Zircons. Int. Geology. Rev. 48 (12), 1067-1086. doi:10.2747/0020-6814.48.12.1067

Liu, F., Xu, Z., and Song, B. (2003). Determination of UHP and Retrograde Metamorphic Ages of the Sulu Terrane:Evidence from SHRIMP U-Pb Dating on Zircons of Gneissic Rocks[J]. Acta. Geologica. Sinica. 77 (2), 229-237.

Liu, Q., and Wu, Y. (2013). Dehydration Melting of UHP Eclogite and Paragneiss in the Dabie Orogen: Evidence from Laboratory experiment to Natural Observation. Chin. Sci. Bull. 58, 4390-4396. doi:10.1007/ s11434-013-6075-9

Liu, X. C., Borming, J., Liu, D. Y., Dong, S. W., and Li, S. Z. (2004). SHRIMP U-Pb Zircon Dating of a Metagabbro and Eclogites from Western Dabieshan (Hong'an Block), China, and its Tectonic Implications. Tectonophysics 394 (3-4), 171-192. doi:10.1016/j.tecto.2004.08.004
Liu, Y, Liu, H, and Xian-hua, L (1996). Simultaneous and Precise Determination of 40 Trace Elements in Rock Samples Using ICP-MS. Geochimica 25 (06), 552-558.

Ludwig, K. R. (2012). Isoplot 3.75 A Geochronological Toolkit for Microsoft Excel, 5. Berkeley: Berkeley Geochronology Center Special Publication, 1-77.

Okay, A. I., Shutong, X., and Sengör, A. M. C. (1989). Coesite from the Dabie Shan Eclogites, central China. ejm 1 (4), 595-598. doi:10.1127/ejm/1/4/0595

Rowley, D. B., Xue, F., Tucker, R. D., Peng, Z. X., Baker, J., and Davis, A. (1997). Ages of Ultrahigh Pressure Metamorphism and Protolith Orthogneisses from the Eastern Dabie Shan: U/Pb Zircon Geochronology[J]. Earth Planet. Sci. Lett. 151 (3-4), 191-203. doi:10.1016/s0012-821x(97)81848-1

Shu-guang, L., Hui-min, L., Yi-zhi, C, Xiao, Y, and De-liang, L (1997). Dabie-Sulu UHP Metamorphic Chronology Body -II. Zircon U-Pb Isotope System. Sci. China,Ser.D. 27 (03), 200-206.

Shu-tian, S., Zeng-qiu, Z., Zhou, H., and You, Z. (2005). Polyphase Tectonometamorphic Evolution of UHP Metamorphic Rocks in the DabieSulu Region, East-central China. Acta Petrologica Sinica 21 (4), 1175-1188. doi:10.3321/j.issn:1000-0569.2005.04.016

Shu-tong, X., Guan-bao, C., Liu, Y., Wu, W., Shu-tian, S., and Zeng-qiu, Z. (2005). Geological Map of Dabie Mountain Orogenic belt (1/500000). Beijing.

Shu-tong, X., Liu, Y., Guan-bao, C., Compagnoni, R., Rolfo, F., He, M., et al. (2003). Diamond from the Dabie Shan-Sulu Area Metamorphic Rocks[J]. Chin. Sci. Bull. 48 (10), 1069-1075. doi:10.1126/science.256.5053.80

Shutong, X., Wen, S., Yican, L., Laili, J., Shouyuan, J., Okay, A. I., et al. (1992). Diamond from the Dabie Shan Metamorphic Rocks and its Implication for Tectonic Setting. Science 256 (5053), 80-82. doi:10.1126/science.256.5053.80

Sun, S.-s., and McDonough, W. F. (1989). Chemical and Isotopic Systematics of Oceanic Basalts: Implications for Mantle Composition and Processes. Geol. Soc. Lond. Spec. Publications 42 (1), 313-345. doi:10.1144/gsl.sp.1989.042.01.19

Tu, X-l., Zhang, H., Deng, W-f., Ling, M-x., Liang, H-y., Liu, Y., et al. (2011). Application of Resolution In-Situ Laser Ablation ICP-MS in Trace Element Analyses. Geochimica. 40 (1), 83-98. in Chinese with English abstract

Wallis, S., Tsuboi, M., Suzuki, K., Fanning, M., Jiang, L., and Tanaka, T. (2005). Role of Partial Melting in the Evolution of the Sulu (Eastern China) UltrahighPressure Terrane. Geol 33 (2), 129-132. doi:10.1130/g20991.1

Wang, Q., and Cong, B. (1998). Tectonic Framework of the Ultrahigh Pressure Metamorphic Zone from the Dabie Mountains. Acta Petrologica Sinica 14 (04), 481-492.

Wang, Q., Xu, J., Wang, J., Zhao, Z., Wang, R., Qiu, J., et al. (2000). The Recognition of Adakite-type Gneisses in the North Dabie Mountain and its Implication to Ultrahigh Pressure Metamorphic Geology. Chin.Sci.Bull. 45 (21), 1927-1933. doi:10.1007/bf02909680

Wang, X, Wen-yuan, C, Liu, S, Zhang, L, and Chun-jing, W (1993). Discovery of Coesite-Bearing Eclogites from Southern Henan Province. Acta Petrologica Sinica 9 (02), 181-185.

Wang, X., Liou, J. G., and Mao, H. K. (1989). Coesite-bearing Eclogite from the Dabie Mountains in central China. Geol 17 (12), 1085-1088. doi:10.1130/00917613(1989)017<1085:cbeftd >2.3.co;2

Wong, J., Sun, M., Xing, G., Li, X. H., Zhao, G., Wong, K., et al. (2009). Geochemical and Zircon $\mathrm{U}-\mathrm{Pb}$ and $\mathrm{Hf}$ Isotopic Study of the Baijuhuajian Metaluminous A-type Granite: Extension at 125-100Ma and its Tectonic Significance for South China. Lithos 112 (3-4), 289-305. doi:10.1016/j.lithos.2009.03.009

Wu, Y., Dao-gong, C., Xia, Q., and Cheng, H. (2001). SIMS U-Pb Dating of Zircons from Shuanghe Orthogneiss, Dabie Area[J]. Bull. Mineralogy Petrol. Geochem. 20 (04), 298-301. Available at: http://espace.library.uq.edu.au/view/UQ:105962

Xue-xie, L., Kang, W., and Pei-cang, X. (1993). Discovery Coesite in Eclogite and Kyante Quartzite from the Dabie Mountains, Henan Province. J. Jilin University(Earth Sci. Edition) 23 (03), 256-261.

Yang, S., Wu, Y., Xiao-chi, L., Wang, M., Peng, M., and Wen-fang, J. (2009). U-pb Ages of Detrital Zircon from Meta-Sedimentary Rock from the Huwan Shear Zone, Western Dabie Terrain and Their Geological Significance. Earth Sci. (Journal China Univ. Geosciences) 34 (01), 179-188. doi:10.3321/j.issn:10002383.2009.01.016

Yuan, Y., Xia, B., Zhang, Y., Lian-ze, X., and He, L. (2015). Geochemical Characteristics and Zircon U-Pb Ages of Gneiss in Luotian Country, Hubei Province. Acta Geologica Sinica 89 (01), 49-57.

Zhang, Y., Xia, B., Liang, H., Liu, H., and Lin, Q. (2004). Characteristics of Zircons for Dating from Daping Mylonitized Alkaline Granite in Yunnan 
and Their Geologic Implications. Geol. J. China Universities 10 (03), 378-384. doi:10.1007/BF02873097

Zheng, X., Cheng-wei, J., Ming-guo, Z., and Shi, Y. (2000). Approach to the Source of the gray Gneisses in North Dabie Terrain: Sm-Nd Isochron Age and Isotope Composition[J]. Acta Petrologica Sinica 16 (2), 194-198

Zheng, Y. F., Fu, B., Gong, B., and Li, L. (2003). Stable Isotope Geochemistry of Ultrahigh Pressure Metamorphic Rocks from the Dabie-Sulu Orogen in China: Implications for Geodynamics and Fluid Regime. Earth-Science Rev. 62 (1-2), 105-61. doi:10.1016/s0012-8252(02)00133-2

Zheng, Y. F., Zhao, Z. F., Wu, Y. B., Zhang, S. B., Liu, X., and Wu, F. Y. (2006). Zircon U-Pb Age, Hf and $\mathrm{O}$ Isotope Constraints on Protolith Origin of Ultrahigh-Pressure Eclogite and Gneiss in the Dabie Orogen. Chem. Geology. 231 (1-2), 135-158. doi:10.1016/j.chemgeo.2006.01.005

Conflict of Interest: Author ZS was employed by the company The 2nd Oil Production Plant of Daqing Oilfield Limited Company.
The remaining authors declare that the research was conducted in the absence of any commercial or financial relationships that could be construed as a potential conflict of interest.

Publisher's Note: All claims expressed in this article are solely those of the authors and do not necessarily represent those of their affiliated organizations, or those of the publisher, the editors, and the reviewers. Any product that may be evaluated in this article, or claim that may be made by its manufacturer, is not guaranteed or endorsed by the publisher.

Copyright (๑) 2022 Shaogong, Yingjie, Yuquan and Zian. This is an open-access article distributed under the terms of the Creative Commons Attribution License (CC $B Y)$. The use, distribution or reproduction in other forums is permitted, provided the original author(s) and the copyright owner(s) are credited and that the original publication in this journal is cited, in accordance with accepted academic practice. No use, distribution or reproduction is permitted which does not comply with these terms. 